\title{
REDD1 Is Involved in Amyloid $\beta$-Induced Synaptic Dysfunction and Memory Impairment
}

\author{
Jee Hyun Yi ${ }^{1,+}$, Huiyoung Kwon ${ }^{2,+}$, Eunbi Cho ${ }^{2,+}$, Jieun Jeon ${ }^{2}$, Jeongwon Lee ${ }^{3}$, \\ Young Choon Lee ${ }^{2}$, Jong Hyun Cho ${ }^{2}$, Mira Jun ${ }^{2}$, Minho Moon ${ }^{4}$, Jong Hoon Ryu ${ }^{5}$, Ji-Su Kim ${ }^{6}$, \\ Ji Woong Choi ${ }^{7}$, Se Jin Park ${ }^{8}$, Seungheon Lee ${ }^{3, *}$ and Dong Hyun Kim ${ }^{2,9, *}$ \\ 1 Center for Synaptic Brain Dysfunctions, Institute for Basic Science, Daejeon 34141, Korea; \\ jeehyunyi@kaist.ac.kr \\ 2 Department of Health Sciences, The Graduate School of Dong-A University, Dong-A University, \\ Busan 49315, Korea; kwonhuiyoung@naver.com (H.K.); bee2634@naver.com (E.C.); ji6785@naver.com (J.J.); \\ yclee@dau.ac.kr (Y.C.L.); jhcho1@dau.ac.kr (J.H.C.); mjun@dau.ac.kr (M.J.) \\ 3 Department of Marine Life Science, Jeju National University, Jeju 63241, Korea; liar0510@naver.com \\ 4 Department of Biochemistry, College of Medicine, Konyang University, Daejeon 35365, Korea; \\ hominmoon@konyang.ac.kr \\ 5 Department of Oriental Pharmaceutical Science, College of Pharmacy, Kyung Hee University, \\ Seoul 02447, Korea; jhryu63@khu.ac.kr \\ 6 Primate Resources Center (PRC), Korea Research Institute of Bioscience and Biotechnology (KRIBB), \\ Jeongup-si, Jeollabuk-do 56216, Korea; kimjs@kribb.re.kr \\ 7 College of Pharmacy and Gachon Institute of Pharmaceutical Sciences, Gachon University, \\ Incheon 21936, Korea; pharmchoi@gachon.ac.kr \\ 8 School of Natural Resources and Environmental Sciences, Kangwon National University, \\ Chuncheon 24341, Korea; sejinpark@kangwon.ac.kr \\ 9 Institute of Convergence Bio-Health, Department of Health Sciences, The Graduate School of \\ Dong-A University, Busan 49315, Korea \\ * $\quad$ Correspondence: slee76@jejunu.ac.kr (S.L.); mose79@dau.ac.kr (D.H.K.); Tel.: +82-51-200-7583 (S.L.) \\ + Authors equally contributed in this study.
}

Received: 20 November 2020; Accepted: 10 December 2020; Published: 13 December 2020

Abstract: Alzheimer's disease (AD) is a neurodegenerative disease characterized by neurological dysfunction, including memory impairment, attributed to the accumulation of amyloid $\beta$ (A $\beta$ ) in the brain. Although several studies reported possible mechanisms involved in $A \beta$ pathology, much remains unknown. Previous findings suggested that a protein regulated in development and DNA damage response 1 (REDD1), a stress-coping regulator, is an $A \beta$-responsive gene involved in $A \beta$ cytotoxicity. However, we still do not know how $A \beta$ increases the level of REDD1 and whether REDD1 mediates A $\beta$-induced synaptic dysfunction. To elucidate this, we examined the effect of $A \beta$ on REDD1-expression using acute hippocampal slices from mice, and the effect of REDD1 short hairpin RNA (shRNA) on A $\beta$-induced synaptic dysfunction. Lastly, we observed the effect of REDD1 shRNA on memory deficit in an AD-like mouse model. Through the experiments, we found that A $\beta$-incubated acute hippocampal slices showed increased REDD1 levels. Moreover, A $\beta$ injection into the lateral ventricle increased REDD1 levels in the hippocampus. Anisomycin, but not actinomycin $\mathrm{D}$, blocked $\mathrm{A} \beta$-induced increase in REDD1 levels in the acute hippocampal slices, suggesting that $\mathrm{A} \beta$ may increase REDD1 translation rather than transcription. A $\beta$ activated Fyn/ERK/S6 cascade, and inhibitors for Fyn/ERK/S6 or mGluR5 blocked A $\beta$-induced REDD1 upregulation. REDD1 inducer, a transcriptional activator, and $\mathrm{A} \beta$ blocked synaptic plasticity in the acute hippocampal slices. REDD1 inducer inhibited mTOR/Akt signaling. REDD1 shRNA blocked A $\beta$-induced synaptic deficits. REDD1 shRNA also blocked A $\beta$-induced memory deficits in passive-avoidance and object-recognition tests. Collectively, these results demonstrate that REDD1 participates in A $\beta$ pathology and could be a target for AD therapy. 
Keywords: Alzheimer's disease; REDD1; A $\beta$; hippocampal long-term potentiation; learning and memory

\section{Introduction}

Alzheimer's disease (AD) is the most common neurodegenerative disease associated with memory and cognitive impairment [1,2]. Although AD is recognized as a global health problem, and various pathological mechanisms have been revealed, appropriate medicine is yet to be developed due to the complex pathogenesis [3-5]. Therefore, new targets for preventing AD are urgently needed.

A stress-inducible protein is "regulated in development and DNA damage response 1" (REDD1), also known as RTP801 or Dig2, which is upregulated in response to a variety of cellular stresses such as nutrient and energy deprivation [6,7], hypoxia [8], DNA damage [9], and stress hormone glucocorticoids $[10,11]$. REDD1, a negative regulator of the mammalian target of rapamycin (mTOR), is involved in transcription and modulates Akt activity by suppressing mTOR via tuberous sclerosis complex 1 (TSC1)/tuberous sclerosis complex 2 (TSC2), and inactivation of Ra homolog enriched in brain (Rheb) [8]. Because mTOR is involved in diverse phenomena, such as autophagy [10], cell proliferation [6], and cell motility [12], its regulation by REDD1 has the potential to be a pharmacological target for various neurological diseases. Metformin, a widely prescribed Type 2 diabetes drug, was found to induce mTOR inhibition and cell-cycle arrest through REDD1 [13].

REDD1 is closely associated with neurological diseases because mTOR is a crucial protein that regulates synapse formation and plasticity $[14,15]$. Hence, an increase in REDD1 expression was observed in patients with Parkinson's disease [16], and dopaminergic neurotoxin 6-OHDA upregulated REDD1 in vitro [17] and in vivo [18]. Moreover, DDIT4, a REDD1 gene, is a gene responding to amyloid $\beta(A \beta)$, a pathological hallmark of Alzheimer's disease [19]. Additionally, it acts as a critical mediator of stress-induced synaptic loss and depressive behavior [20]. Previous findings indicated that REDD1 is upregulated by $A \beta$, and the antisense of DDIT4 inhibits $A \beta$ cytotoxicity [19]. However, we still do not know how $A \beta$ increases REDD1 levels and how REDD1 is involved in $A \beta$ toxicity. To elucidate this, we examined the mechanism of $A \beta$-induced REDD1 upregulation and the role of REDD1 in $A \beta$-induced synaptic deficits using acute hippocampal slices from mice. Lastly, we examined the effect of REDD1 knockdown in memory deficits in AD-like mice models.

\section{Results}

\subsection{A Increased REDD1 Levels in the Hippocampus}

To examine whether A $\beta$ regulates REDD1 expression, we tested the REDD1 levels in A $\beta$-treated hippocampal slices from mice. The hippocampal slices, treated with $A \beta(1 \mu \mathrm{M})$ for $4 \mathrm{~h}$, showed significantly increased REDD1 levels $\left(\mathrm{t}_{6}=7.802, p<0.05, \mathrm{n}=4\right.$ /group; Figure $\left.1 \mathrm{~A}\right)$. Moreover, intracerebroventricular injection of $\mathrm{A} \beta(10 \mu \mathrm{M}, 3 \mu \mathrm{L})$ into the hippocampal CA1 region increased REDD1 levels $24 \mathrm{~h}$ postinjection $\left(\mathrm{t}_{6}=3.871, p<0.05, \mathrm{n}=4\right.$ /group; Figure $\left.1 \mathrm{~B}\right)$. These results suggest that $\mathrm{A} \beta$ may upregulate REDD1. 
A

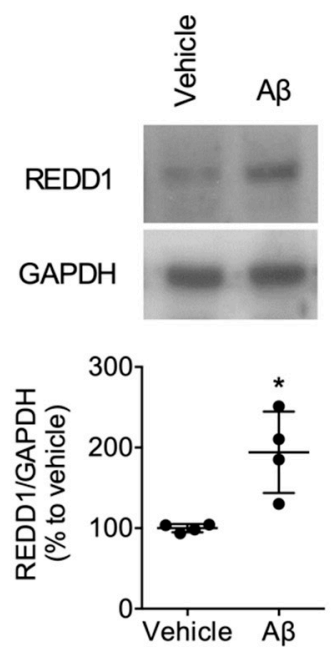

B

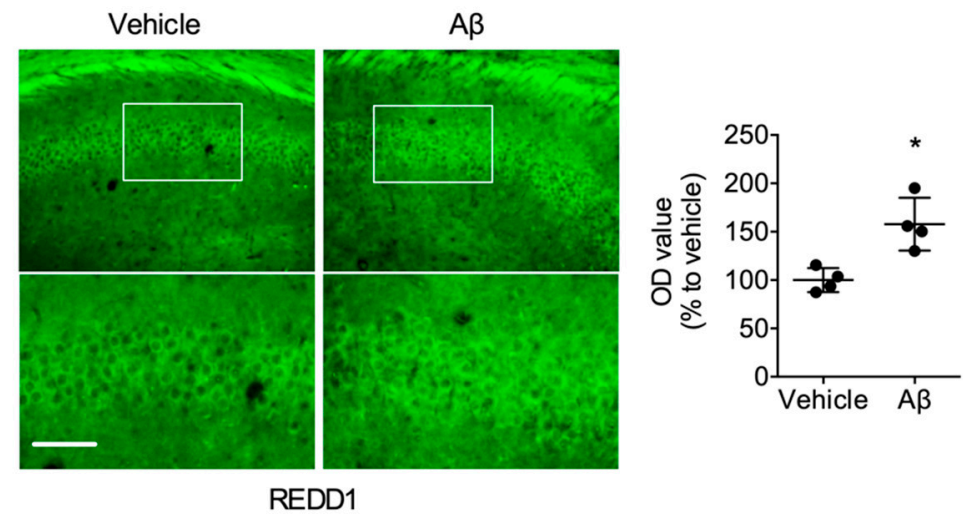

Figure 1. Amyloid $\beta(A \beta)$ increased regulated in development and DNA damage response 1 (REDD1) protein levels in the hippocampus. (A) A $\beta$-induced REDD1 upregulation. Hippocampal slices were incubated with $A \beta$ for $4 \mathrm{~h}$. (B) $\mathrm{A} \beta$-induced REDD1 upregulation in the hippocampus. $\mathrm{A} \beta$ was injected into the fissure layer of the hippocampal CA1 region. Bar $=50 \mu \mathrm{m}$. Data represented as mean \pm SD with raw data. ${ }^{*} p<0.05$ vs. vehicle-treated group.

\subsection{Fyn/ERK/S6 Signaling Is Involved in A $\beta$-Induced REDD1 Translation}

To test whether $A \beta$ affects REDD1 transcription or translation, we tested anisomycin and actinomycin $D$ in the acute hippocampal slices. In this experiment, anisomycin, but not actinomycin $D$, blocked $A \beta$-induced upregulation of REDD1 (Figure $2 A, B$ ), suggesting that $A \beta$ regulated the translation of REDD1. Previous studies suggested that A $\beta$ affected Fyn/ERK/S6 signaling, which is involved in protein translation [21]. Therefore, we tested whether this signaling was also involved in $A \beta$-induced REDD1 overexpression in the hippocampal tissue. $\mathrm{A} \beta(1 \mu \mathrm{M}$ for $4 \mathrm{~h})$ significantly increased Fyn/ERK/S6 signaling in the hippocampus (Figure 2C,D). Next, to test whether this signaling is required for $A \beta$-induced upregulation of REDD1, we tested inhibitors of these molecules in the hippocampal tissue. PP1, a Fyn inhibitor; U0126, an ERK inhibitor; SL0101-1, a S6 inhibitor; and MPEP, an mGluR5 inhibitor blocked A $\beta$-induced upregulation of REDD1 in the hippocampal tissue (Figure 2E,F). These results suggest that Fyn/ERK/S6 signaling is involved in A $\beta$-induced upregulation of REDD1.

\subsection{REDD1 Is Required for A $\beta$-Induced Synaptic Dysfunction}

To determine if REDD1 is a mediator of $A \beta$-induced synaptic dysfunction, we tested the effects of a REDD1 inducer, a transcriptional inducer [22,23], and REDD1 shRNA in synaptic plasticity. REDD1 inducer (50 $\mu \mathrm{M}$ for $4 \mathrm{~h}$ ) blocked high-frequency stimulation (HFS)-induced long-term potentiation (LTP) induction ( $t_{8}=3.737, p<0.05, \mathrm{n}=5$ /group; Figure $3 \mathrm{~A}$ ). Moreover, REDD1 inducer decreased mTOR/Akt signaling in the hippocampal slices (Figure 3B). These results suggest that REDD1 activation negatively regulates synaptic plasticity and inhibits mTOR/Akt signaling.

Next, to test whether REDD1 is required for $A \beta$-induced synaptic dysfunction, we tested the effect of REDD1 shRNA on A $\beta$-induced synaptic dysfunction. $A \beta(1 \mu \mathrm{M}$ for $4 \mathrm{~h})$, which was aggregated for $24 \mathrm{~h}$, blocked hippocampal LTP, which is induced by HFS ( $t_{8}=3.901, p<0.05, n=5$ /group; Figure $\left.3 \mathrm{C}\right)$. Seven days after the injections of REDD1 shRNA, hippocampal slices from mice were prepared for electrophysiology (Figure 3D). A $\beta$ treatment significantly suppressed LTP levels in the scramble-treated hippocampal slices. In the short hairpin REDD1 (shREDD1)-injected hippocampal slices, $A \beta$ failed to 
suppress LTP levels, suggesting that REDD1 is required for A $\beta$-induced synaptic deficit $\left(F_{2,12}=7.709\right.$, $p<0.05, n=5$ /group; Figure 3D).

A

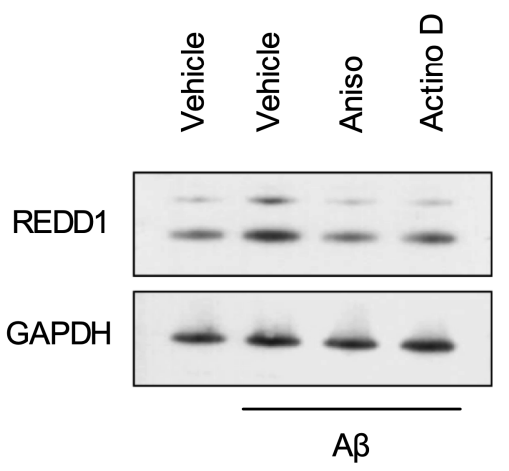

C

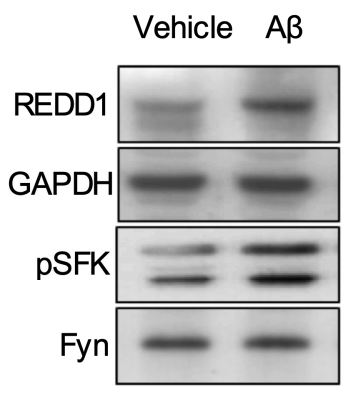

$E$

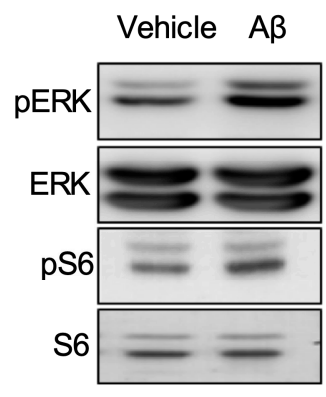

B

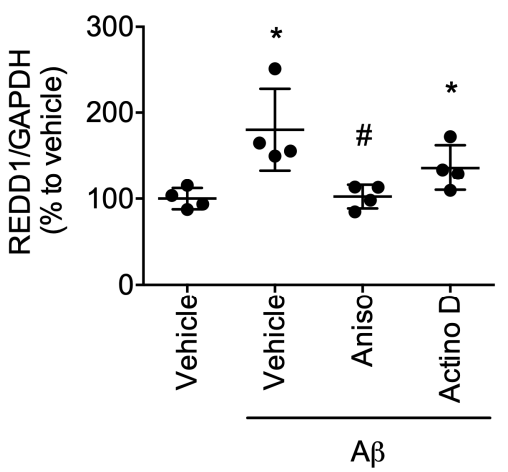

$\mathrm{D}$ $\square$ Vehicle

$A \beta$

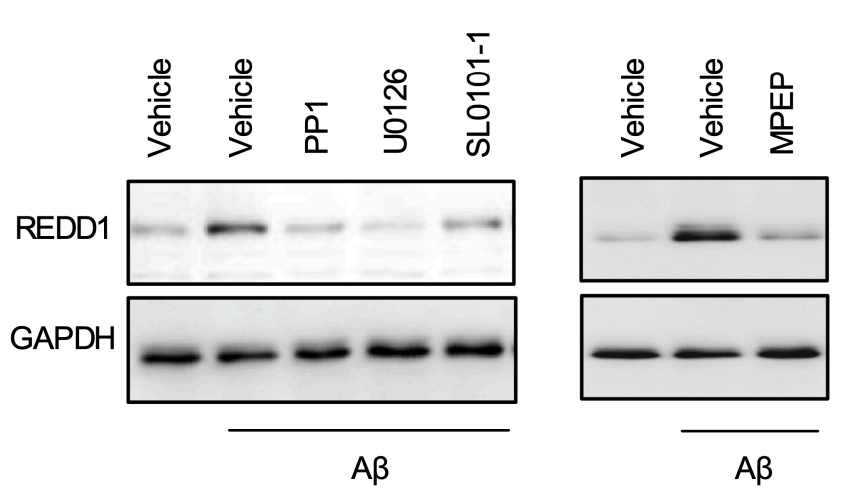

$\mathrm{F}$

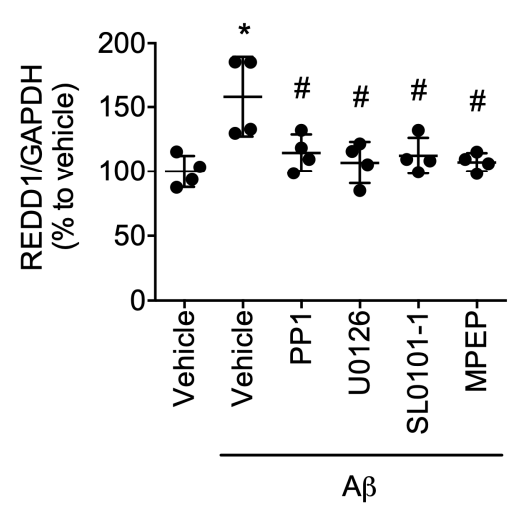

Figure 2. Fyn/ERK/S6 signaling is involved in A $\beta$-induced REDD1 translation. (A,B) A $\beta$ increased REDD1 with translational modulation. Hippocampal slices were incubated with $A \beta$ for $4 \mathrm{~h}$ with or without anisomycin $(40 \mu \mathrm{M})$ or actinomycin D $(50 \mu \mathrm{M})$. (C,D) A $\beta$ activated Fyn/ERK/S6 signaling. Hippocampal slices were incubated with $A \beta$ for 4 h. (E,F) Fyn/ERK/S6 signaling is required for $A \beta$-increased REDD1. Hippocampal slices were incubated with $A \beta$ for $4 \mathrm{~h}$ with or without PP1 $(10 \mu \mathrm{M})$, U0126 $(50 \mu \mathrm{M})$, SL0101-1 $(50 \mu \mathrm{M})$, or MPEP $(10 \mu \mathrm{M})$. Data represented as mean \pm SD with raw data. * $p<0.05$ vs. vehicle-treated group. \# $p<0.05$ vs. A $\beta$-treated group. 
A

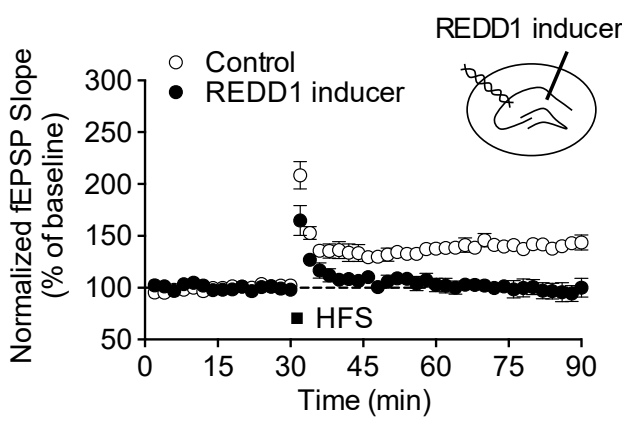

B
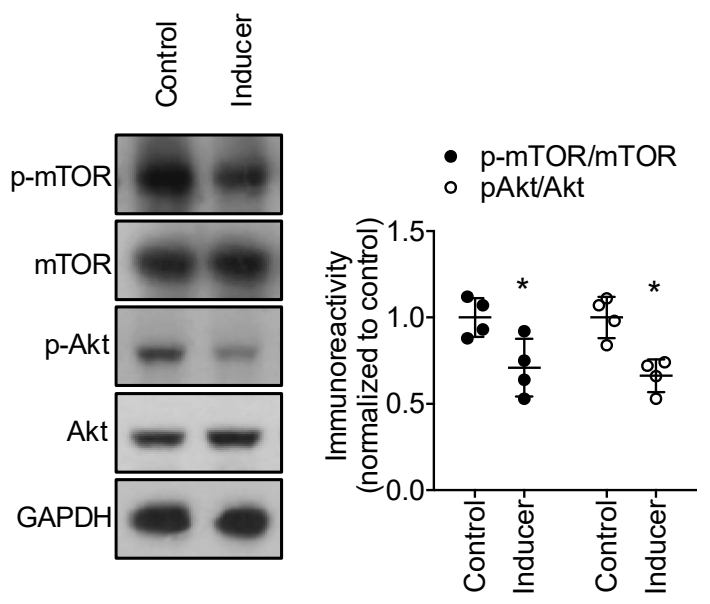

C

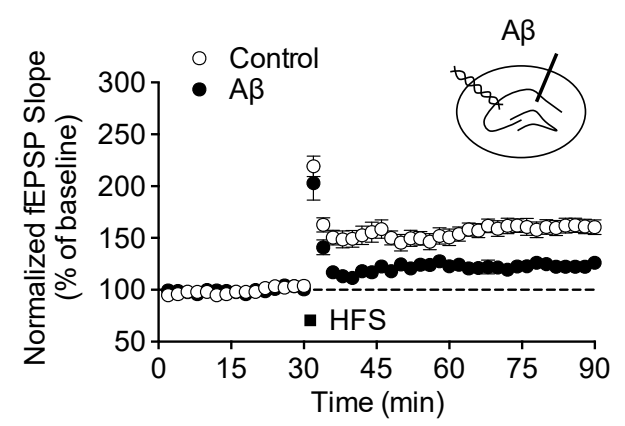

D

ShRNA
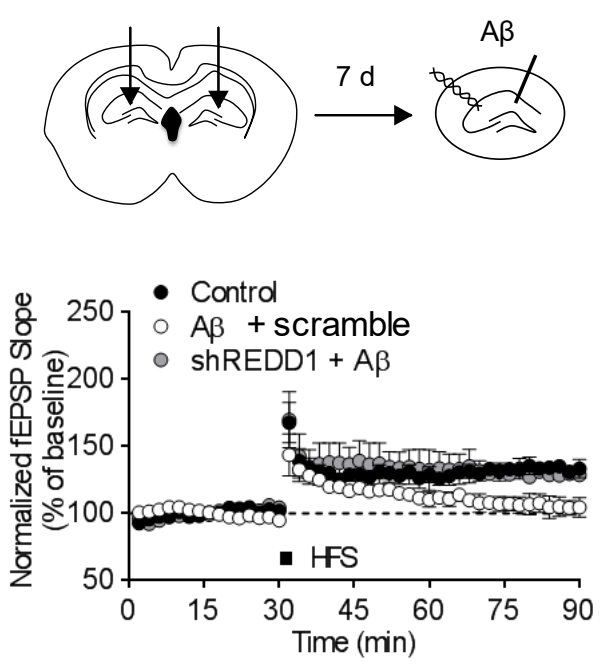

Figure 3. REDD1 is required for A $\beta$-induced synaptic dysfunction. (A) REDD1 inducer suppressed hippocampal long-term potentiation (LTP). Hippocampal slices incubated with REDD1 inducer $(50 \mu \mathrm{M})$ for $4 \mathrm{~h}$. Data represented as mean \pm SD. (B) REDD1 inducer suppressed mTOR signaling in the hippocampus. Data represented as mean \pm SD with raw data. (C) A $\beta$ suppressed hippocampal LTP. Hippocampal slices incubated with $\mathrm{A} \beta(1 \mu \mathrm{M})$ for $4 \mathrm{~h}$. Data represented as mean \pm SD. (D) REDD1 knockdown blocked A $\beta$-induced LTP impairment. REDD1 shRNA (m) lentiviral particle or scramble lentiviral particle was bilaterally injected into hippocampal fissure layer. Hippocampal slices prepared and incubated with $A \beta$ for $4 \mathrm{~h}, 7 \mathrm{~d}$ after lentiviral injection. Data represented as mean $\pm \mathrm{SD}$.

\subsection{REDD1 Knockdown Rescued A $\beta$-Induced Memory Impairments}

To determine whether REDD1 is involved in A $\beta$-induced memory impairments, we used an intracerebroventricular injection of the $A \beta$ model [24]. $A \beta$ was injected into the lateral ventricle 7 days after shREDD1 injection. Behavioral tests were conducted 7 days after $A \beta$ injection (Figure 4A). In the passive-avoidance test, shREDD1 or A $\beta$ injection did not affect step-through latency in the acquisition trial $\left(\mathrm{F}_{2,19}=0.7345, p>0.05, n=7-8\right.$ /group; Figure $\left.4 \mathrm{~B}\right)$. In the test trial of the passive-avoidance test, $A \beta$ reduced step-through latency in scramble-injected mice, but not in shREDD1-injected mice $\left(\mathrm{F}_{2,19}=7.141, p<0.05, n=7-8\right.$ /group; Figure $\left.4 \mathrm{C}\right)$. The object-recognition test revealed no significant difference in total exploration time $\left(\mathrm{F}_{2,19}=0.794, p>0.05, \mathrm{n}=7-8 /\right.$ group, Figure $\left.4 \mathrm{D}\right)$. Discrimination index showed that $A \beta$ impaired recognition memory, and shREDD1 blocked this impairment $\left(F_{3,26}=17.95, p<0.05, n=7-8\right.$ /group; Figure 4E). These results suggest that REDD1 knockdown abolished $\mathrm{A} \beta$-induced memory loss. 
A

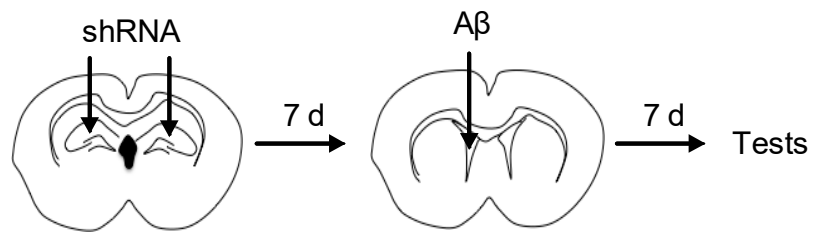

B

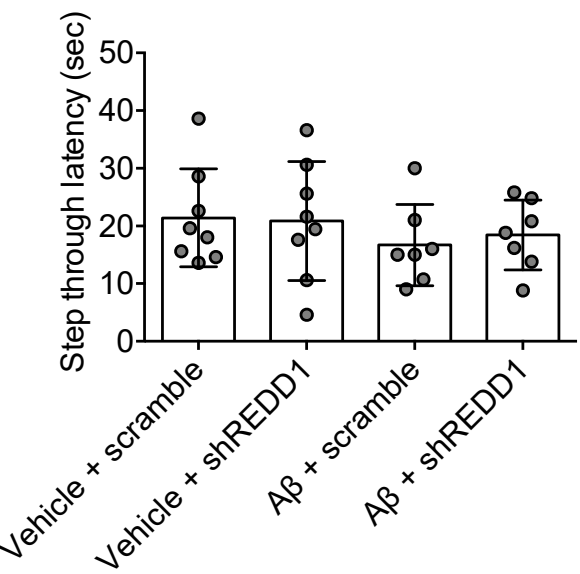

$\mathrm{D}$

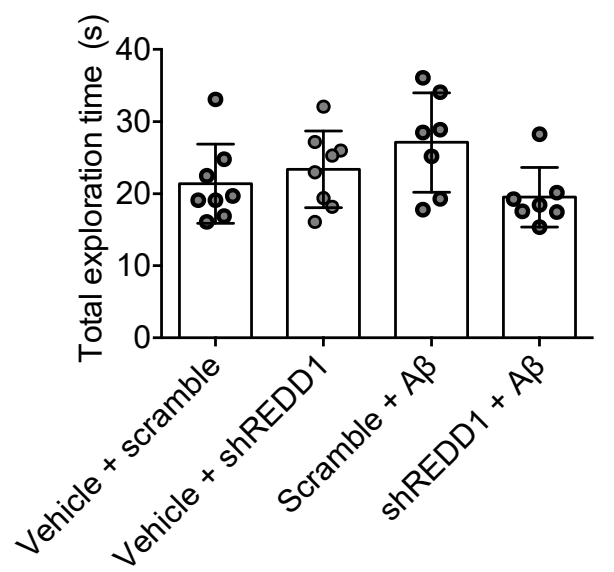

C

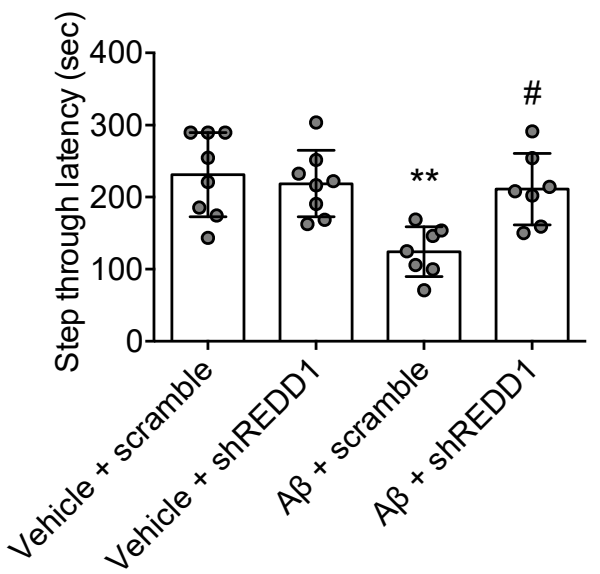

$E$

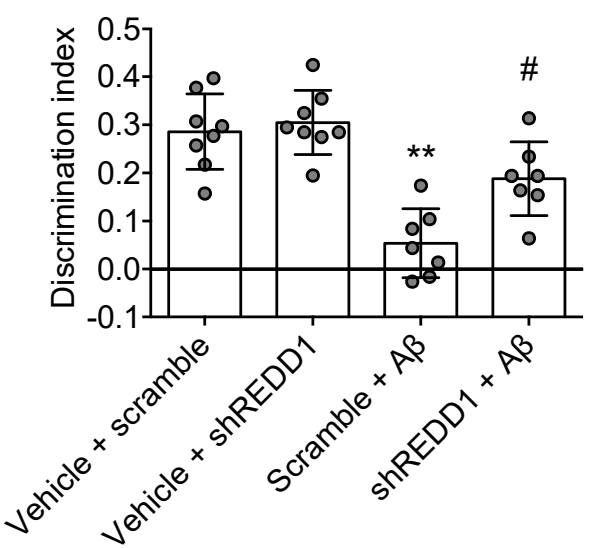

Figure 4. REDD1 reduction rescued A $\beta$-induced memory impairment. (A) REDD1 shRNA (m) lentiviral particle or control lentiviral particle was bilaterally injected into hippocampal fissure layer. A $\beta$ was injected into the lateral ventricle $7 \mathrm{~d}$ later than the shRNA injection was. (B,C) REDD1 knockdown blocked A $\beta$-induced passive-avoidance memory deficit. Data represented as mean \pm SD. ${ }^{* *} p<0.01$ vs. sham group; $\# p<0.05$ vs. scramble $+\mathrm{A} \beta$ group. (D,E) REDD1 knockdown blocked A $\beta$-induced object-recognition memory deficit. Data represented as mean \pm SD. \# $p<0.05$. ${ }^{* *} p<0.01$.

\section{Discussion}

In the present study, REDD1, an mTORC1 repressor, was found to be upregulated by $A \beta$, which requires Fyn/ERK/S6 cascade. REDD1 is required for A $\beta$-induced synaptic deficit and memory loss. REDD1 blocked memory loss in an AD-like mouse model, suggesting that REDD1 could be a potential pharmacological target for memory loss in AD patients. 
REDD1 is an upstream repressor of mTORC1 signaling and is upregulated in response to various stressors [25-27]. REDD1 expression is induced by protein expression as part of the endoplasmic reticulum stress response, including activating transcription factor 4 (ATF4) [28]. Upregulation of REDD1 was found in an AD brain [29,30]. However, the mechanism of upregulation of REDD1 and its role in AD are yet to be elucidated. A $\beta$ increased the mRNA levels of REDD1, and the antisense REDD1 gene blocked $A \beta$ cytotoxicity [19]. In the present study, we found that REDD1 is required for $\mathrm{A} \beta$ synaptotoxicity and AD-like memory impairment.

REDD1 is also upregulated in other brain diseases, including major depressive disorder [20,27]. REDD1 is required for stress-induced synaptic loss and depressive behavior. This process requires mTOR suppression-induced repression of translation of synaptic proteins, which results in basal synaptic deficit. In the present study, REDD1 activator suppressed hippocampal LTP in the Shaffer collateral pathway, suggesting that REDD1 suppresses either basal synaptic functions or synaptic plasticity. REDD1 suppresses mTORC1 [31,32]. Various synaptic stimulations, including glutamate and neurotrophins, activate mTORC1, thereby stimulating protein translation-induced changes in the synapse [33-35]. mTORC1 induces translocation of the AMPA receptor to the synaptic region via the S6K1 pathway [36,37]. PERK, mTORC1, and eEF2 interact during LTP induction [38]. These studies demonstrated that REDD1 upregulation could induce synaptic dysfunction through mTORC1 suppression, and this may be a mechanism of synaptic deficit in various stressful conditions of the brain, including AD. In the present study, we found that A $\beta$ upregulated REDD1. Suppression of REDD1 expression with shRNA blocked $A \beta$-induced synaptic plasticity impairment, suggesting that REDD1 is a mediator of $A \beta$ synaptotoxicity.

Controversial data were obtained regarding the role of mTOR in AD. In AD patients, mTORC1 was upregulated in the brain [39]. In Tg2576 mice, mTOR knockdown reduced amyloid deposits and ameliorated memory impairment [40]. Rapamycin, an mTOR inhibitor, decreased amyloid deposits and tau tangles, and reduced cognitive deficits in 3xTg and PDAPP mice [41,42]. However, several studies reported the downregulation of mTOR signaling in the Tg2576 model [43,44]. This could be due to differences in different mTOR complexes, including mTOR complex 1 (mTORC1) and complex 2 (mTORC2). The mTORC1 complex plays a critical role in synaptic plasticity [45-47]. However, the precise role of mTORC2 is yet to be elucidated. Several studies revealed that mTORC2 may be involved in myelination of oligodendrocyte [48] and glutamate synaptic transmission [49]. Prolonged, but not acute, treatment with rapamycin was reported to lead to interference with mTORC2 [50]. These data suggest that mTORC1 and mTORC2 might be differently modulated by rapamycin and $\mathrm{A} \beta$.

Collectively, the present study demonstrates that REDD1 is required for A $\beta$-induced synaptic dysfunction and memory impairment. However, REDD1 is not involved in the process of A $\beta$ generation and metabolism.

\section{Materials and Methods}

\subsection{Animals}

CD-1 mice weighing 25-30 g (male, 6 weeks old) were purchased from Samtako (Osan, Korea). The mice were habituated to the living environment for 1 week before each experiment. Experiments were started with 7 week old mice. Mice had freely available food and water, and were bred in a space with a 12/12 h dark/light cycle. Animals were raised according to National Institutes of Health (NIH) guidelines for the care and use of laboratory animals (NIH publications no. 8023, revised 1978), and all experiments were approved by the Institutional Animal Care and Use Committee at Dong-A University (DIACUC-approve-20-5, 20 May 2020). 


\subsection{Materials}

Rabbit anti-REDD1, rabbit anti-GAPDH, rabbit antiphosphorylated extracellular signal-regulated kinase (pERK), rabbit anti-ERK, mouse anti-mTOR, and rabbit anti-Akt antibodies were purchased from Santa Cruz Biotechnology (Santa Cruz, CA, USA). Rabbit antiphosphorylated Src family kinase (pSFK), rabbit anti-Fyn, rabbit anti-pS6, and rabbit anti-S6 antibodies were purchased from Cell Signaling Technology (Beverly, MA, USA). A $\beta_{1-42}$ was purchased from AnaSpec (San Jose, CA, USA). REDD1 shRNA $(\mathrm{m})$ lentiviral particles were purchased from Santa Cruz Biotechnology (sc-45807-V, Santa Cruz, CA, USA). Anisomycin, actinomycin D, PP1, U0126, SL0101-1, and MPEP were purchased from Tocris Bioscience (Ellisville, MO, USA). 6-(1,3-Dioxo-6-(piperidin-1-yl)-1H-benzo[de]isoquinolin-2(3H)-yl)hexanoic acid (REDD1 inducer) was purchased from Sigma-Aldrich (St. Louis, MO, USA) [23]. All other materials were obtained from normal commercial sources and were of the highest grade available.

\section{3. $A \beta_{1-42}$ Preperation and Injection}

We added $1.0 \% \mathrm{NH}_{4} \mathrm{OH}$ directly to the $\mathrm{A} \beta_{1-42}(35-40 \mu \mathrm{L}$ to $0.5 \mathrm{mg}$ peptide or $70-80 \mu \mathrm{L}$ to $1 \mathrm{mg}$ peptide). This solution was immediately diluted with $1 \mathrm{X}$ phosphate-buffered saline (PBS) to a concentration of $1 \mathrm{mg} / \mathrm{mL}$. The solution was gently vortexed and sonicated at room temperature until fully miscible. $\mathrm{A} \beta_{1-42}(10 \mu \mathrm{M})$ was incubated at $37^{\circ} \mathrm{C}$ for $24 \mathrm{~h}$ to obtain various soluble oligomeric species, and $5 \mu \mathrm{L}$ of $\mathrm{A} \beta$ or vehicle (PBS) was then acutely injected into the left lateral ventricle by hand under isoflurane anesthesia (induction 3\% and maintenance 2\%) [51]. Experiments started 7 days after the injection.

\subsection{REDD1 shRNA Injection}

REDD1 shRNA (m) lentiviral particles were bilaterally injected into the hippocampal fissure layer. Mice were placed in a stereotaxic frame (David Kopf Instruments, Tujunga, CA, USA) under isoflurane anesthesia (induction $3 \%$ and maintenance $2 \%$ ). Target injection site coordinates were as follows: AP, $2.0 \mathrm{~mm}$; ML, $\pm 1.25 \mathrm{~mm}$; DV, $1.75 \mathrm{~mm}$ [52]. Injections were performed using a $5 \mu \mathrm{L}$ Hamilton syringe operated by a Harvard Apparatus Pump II Dual Syringe micropump. Needles were left in place for an additional $60 \mathrm{~s}$ to allow for the fluid to diffuse. Each side was injected individually, one immediately after the other, with $2 \mu \mathrm{L} /$ side of REDD1 shRNA (m) lentiviral particles $\left(1 \times 10^{7}\right.$ in $2 \mu \mathrm{L}$ ) at a rate of $0.2 \mu \mathrm{L} / \mathrm{min}$.

\subsection{Immunohistochemistry for REDD1}

Mice were anesthetized using isoflurane ( $3 \%$ ) at $24 \mathrm{~h}$ after $\mathrm{A} \beta$ injection, and perfused transcardially with $100 \mathrm{mM}$ phosphate buffer ( $\mathrm{pH} 7.4$ ), followed by ice-cold $4 \%$ paraformaldehyde. Brains were removed and postfixed in phosphate buffer $(50 \mathrm{mM}$, pH 7.4) containing $4 \%$ paraformaldehyde overnight. Brains were immersed in a solution containing $30 \%$ sucrose in $50 \mathrm{mM}$ phosphate-buffered saline (PBS) and stored at $4{ }^{\circ} \mathrm{C}$ until sectioning. Frozen brains were coronally sectioned on a cryostat at $30 \mu \mathrm{m}$, and sections including the hippocampal area (from $-1.50 \mathrm{~mm}$ posterior to the bregma as defined in the mouse brain atlas) were stored in a storage solution at $4{ }^{\circ} \mathrm{C}$.

Free-floating sections (thickness, $30 \mu \mathrm{m})$ were incubated for $24 \mathrm{~h}$ in PBS $\left(4{ }^{\circ} \mathrm{C}\right)$ containing rabbit anti-REDD1 (1:500 dilution), 0.3\% Triton X-100, and 1.5\% normal serum. Sections were incubated for 90 min with FITC-conjugated secondary antibody (1:1000 dilution). Lastly, the stained brain sections were mounted onto glass slides using Richard-Allan Scientific mounting medium (Thermo Scientific, Waltham, MA, USA). Images of histochemical samples were obtained with a Zeiss LSM 700 (Carl Zeiss AG, Oberkochen, German), and images were analyzed using ImageJ software (NIH, Bethesda, MD, USA). For the analysis of REDD1 immunoreactivity, the CA1 regions of hippocampal tissue were quantified. Quantification of REDD1 immunoactivity was performed by determining the percentage of fluorescence intensity using ImageJ software (NIH, Bethesda, MD, USA). 


\subsection{Acute-Hippocampal-Slice Preparation}

Artificial cerebrospinal fluid (ACSF) was composed of $\mathrm{NaCl}(124 \mathrm{mM}), \mathrm{KCl}(3 \mathrm{mM}), \mathrm{NaHCO}_{3}(26 \mathrm{mM})$, $\mathrm{NaH}_{2} \mathrm{PO}_{4}(1.25 \mathrm{mM}), \mathrm{CaCl}_{2}(2 \mathrm{mM}), \mathrm{MgSO}_{4}(1 \mathrm{mM})$, and D-glucose $(10 \mathrm{mM})$. We rapidly isolated the mouse hippocampus and submerged it in chilled ACSF. For tissue slicing, we used McIlwain tissue chopper. Hippocampal slices of $400 \mu \mathrm{m}$ thickness were incubated in ACSF $\left(20-25^{\circ} \mathrm{C}, 2 \mathrm{~h}\right)$ before the experiment.

\subsection{Western Blot}

Acute hippocampal slices were used for mechanism studies. To see the effect of A $\beta$ on REDD1 production and signaling, acute hippocampal slices were incubated with $\mathrm{A} \beta(10 \mu \mathrm{M})$-containing ACSF for $4 \mathrm{~h}$. For the blocking test, acute hippocampal slices were incubated with drug (inhibitors)-containing ACSF for $30 \mathrm{~min}$, and then were incubated with $\mathrm{A} \beta(10 \mu \mathrm{M})+$ drug-containing ACSF for $4 \mathrm{~h}$ further. After incubation, the hippocampal slices were homogenized in ice-cold homogenize buffer $(0.32 \mathrm{M}$ sucrose, $1 \mathrm{mM}$ EDTA, $1 \mathrm{mM}$ EGTA, $1 \mathrm{mM}$ PMSF, $1 \mathrm{mM}$ sodium orthovanadate, one protease inhibitor cocktail tablet (Roche, Seoul, Korea) per $50 \mathrm{~mL}$ of buffer in $20 \mathrm{mM}$ Tris-HCl buffer (pH 7.4)). Proteins from the lysates were quantified using a BCA protein assay kit. Proteins (100 $\mu \mathrm{g}$ for caspase-3 or $30 \mu \mathrm{g}$ for others) were subjected on SDS-PAGE gels for electrophoresis and transferred to PVDF membranes at $300 \mathrm{~mA}$ for $2 \mathrm{~h}$ at $4{ }^{\circ} \mathrm{C}$ in transfer buffer $(25 \mathrm{mM}$ Tris- $\mathrm{HCl}$ (pH 7.4) containing $192 \mathrm{mM}$ glycine and $20 \% \mathrm{v} / \mathrm{v}$ methanol). The Western blots were then incubated for $1 \mathrm{~h}$ with a blocking solution ( $2 \%$ BSA or $5 \%$ skim milk), then with primary antibodies overnight at $4{ }^{\circ} \mathrm{C}$, washed ten times with Tween20/Tris-buffered saline (TTBS), incubated with a 1:2000 dilution of horseradish peroxidase-conjugated secondary antibodies for $2 \mathrm{~h}$ at room temperature, washed ten times with TTBS, and finally developed by enhanced chemiluminescence (Amersham LifeScience, Arlington Heights, IL, USA).

\subsection{Electrophysiology}

Field excitatory postsynaptic potential (fEPSP) was recorded in the CA1 area (Schaffer collateral-commissural pathway) of the acute hippocampal slices. Constant stimuli were delivered through stimulating electrode $(0.033 \mathrm{~Hz})$. The slope of the evoked fEPSP was averaged over consecutive recordings evoked at $30 \mathrm{~s}$ intervals. $30 \mathrm{~min}$ after the initiation of a stable baseline, high-frequency stimulation (HFS: 2 trains of 100 pulses at $100 \mathrm{~Hz}$ with $30 \mathrm{~s}$ interval) was introduced to induce long-term potentiation (LTP). LTP was quantified by comparing the mean fEPSP slope at 80 min after the TBS with the mean fEPSP slope during the baseline period. To test the effect of the REDD1 inducer or $\mathrm{A} \beta$ on hippocampal LTP, acute hippocampal slices were incubated with REDD1 inducer $(10 \mu \mathrm{M})$ or $\mathrm{A} \beta(10 \mu \mathrm{M})$ before recording (Figure 3A,C). To test the effect of REDD1 shRNA on A $\beta$-induced hippocampal LTP deficits, REDD1 shRNA was injected into the hippocampi of the mice, and acute hippocampal slices were prepared from the mice $7 \mathrm{~d}$ after the injection. Acute hippocampal slices were incubated with $\mathrm{A} \beta(10 \mu \mathrm{M})$ for $4 \mathrm{~h}$ before recording (Figure $3 \mathrm{D})$.

\subsection{Passive-Avoidance Test}

To test the effect of REDD1 shRNA on A $\beta$-induced memory deficit, REDD1 shRNA was injected into the hippocampi of mice, and $A \beta$ was injected into the lateral ventricles of the mice $7 \mathrm{~d}$ after the shRNA injection. Passive avoidance started $7 \mathrm{~d}$ after the $\mathrm{A} \beta$ injection. The passive-avoidance box was composed of 2 rooms, namely, a dark and an illuminated room, which were separated with a guillotine door. In a training session, a mouse was located in the illuminated room, and the guillotine door opened $10 \mathrm{~s}$ later. When the mouse crossed the guillotine door and entered the dark room, the door closed, and $0.5 \mathrm{~mA}$ of electric shock was delivered through the grid floor. The next day, the mouse was relocated to the illuminated room and the guillotine door opened $10 \mathrm{~s}$ later. Latency time to enter the 
dark room was measured by $300 \mathrm{~s}$. Behavioral tests and quantification were performed by investigators blind to the groups.

\subsection{Object-Recognition Test}

One day after the passive-avoidance test, the mice were habituated to the open field $(25 \times 25$ $\times 25 \mathrm{~cm}$ ) with an internal cue on one of the four walls for $10 \mathrm{~min}$. Thirty minutes after habituation, the mice were re-placed in the same box with two distinct objects. The objects consisted of a glass box and a plastic cylinder. Mice were allowed to freely explore the objects for $10 \mathrm{~min}$. After $2 \mathrm{~h}$, mice were placed back into the same box for the test phase. The two objects were again present, but one object was now displaced to a novel one (metal ball). Mice were allowed to freely explore the environment and the objects for $5 \mathrm{~min}$. Time spent exploring the displaced and nondisplaced objects was measured using video-based Ethovision XT System (Noldus, Wageningen, The Netherlands). Behavioral tests and quantification were performed by investigators blind to the groups.

\subsection{Statistics}

All statistical analyses and graphs were performed using GraphPad Prism version 5.0 (GraphPad, San Diego, CA, USA). All in vitro experiments were repeated three times. For multiple comparisons, data were analyzed by one-way analysis of variance (ANOVA) followed by Turkey's test for significance between groups. The $t$ test was only used for comparison between the two groups. Data are expressed as means $\pm \mathrm{SD}$ with raw data. Statistical significance was set at $p<0.05$.

Author Contributions: Conceptualization, J.H.Y. and D.H.K.; methodology, H.K. and E.C.; validation, J.H.Y., H.K. and D.H.K.; formal analysis, E.C., J.L. and Y.C.L.; investigation, H.K., E.C., J.J. and J.H.C.; resources, J.H.C., M.J., and M.M.; data curation, J.L., S.J.P., and S.L.; writing-original-draft preparation, J.H.Y., H.K., and E.C.; writing-review and editing, S.L. and D.H.K.; visualization, J.H.R. and J.-S.K.; supervision, S.L. and D.H.K.; project administration, J.-S.K. and D.H.K.; funding acquisition, J.S.K. and J.W.C. All authors have read and agreed to the published version of the manuscript.

Funding: This work was supported by the BB21 Plus project, a National Research Foundation of Korea (NRF) grant funded by the Korean government (nos. 2017R1C1B1003822, 2016R1A5A2007009), and a grant from the KRIBB Research Initiative Program (KGM5162021).

Conflicts of Interest: The authors declare no conflict of interest.

\section{Abbreviations}

$\begin{array}{ll}\text { AD } & \text { Alzheimer's disease } \\ \text { A } \beta & \text { Amyloid } \beta \\ \text { REDD1 } & \text { Regulated in development and DNA damage response 1 } \\ \text { TSC } & \text { Tuberous sclerosis complex } \\ \text { ERK } & \text { Extracellular signal regulated kinase } \\ \text { SFK } & \text { Src family kinase } \\ \text { PBS } & \text { Phosphate-buffered saline } \\ \text { ACSF } & \text { Artificial cerebrospinal fluid } \\ \text { TTBS } & \text { Tween20/Tris-buffered saline } \\ \text { fEPSP } & \text { Field excitatory postsynaptic potential } \\ \text { HFS } & \text { High-frequency stimulation } \\ \text { LTP } & \text { Long-term potentiation }\end{array}$




\section{References}

1. Weissberger, G.H.; Strong, J.V.; Stefanidis, K.B.; Summers, M.J.; Bondi, M.W.; Stricker, N.H. Diagnostic Accuracy of Memory Measures in Alzheimer's Dementia and Mild Cognitive Impairment: A Systematic Review and Meta-Analysis. Neuropsychol. Rev. 2017, 27, 354-388. [CrossRef] [PubMed]

2. Celone, K.A.; Calhoun, V.D.; Dickerson, B.C.; Atri, A.; Chua, E.F.; Miller, S.L.; DePeau, K.; Rentz, D.M.; Selkoe, D.J.; Blacker, D.; et al. Alterations in memory networks in mild cognitive impairment and Alzheimer's disease: An independent component analysis. J. Neurosci. 2006, 26, 10222-10231. [CrossRef] [PubMed]

3. Van Dam, D.; De Deyn, P.P. Animal models in the drug discovery pipeline for Alzheimer's disease. Br. J. Pharmacol. 2011, 164, 1285-1300. [CrossRef] [PubMed]

4. Cummings, J.L.; Morstorf, T.; Zhong, K. Alzheimer's disease drug-development pipeline: Few candidates, frequent failures. Alzheimers Res. Ther. 2014, 6, 37. [CrossRef] [PubMed]

5. Gong, C.X.; Liu, F.; Iqbal, K. Multifactorial Hypothesis and Multi-Targets for Alzheimer's Disease. J. Alzheimers Dis. 2018, 64, S107-S117. [CrossRef]

6. Sofer, A.; Lei, K.; Johannessen, C.M.; Ellisen, L.W. Regulation of mTOR and cell growth in response to energy stress by REDD1. Mol. Cell. Biol. 2005, 25, 5834-5845. [CrossRef]

7. McGhee, N.K.; Jefferson, L.S.; Kimball, S.R. Elevated corticosterone associated with food deprivation upregulates expression in rat skeletal muscle of the mTORC1 repressor, REDD1. J. Nutr. 2009, 139, 828-834. [CrossRef]

8. $\quad$ Brugarolas, J.; Lei, K.; Hurley, R.L.; Manning, B.D.; Reiling, J.H.; Hafen, E.; Witters, L.A.; Ellisen, L.W.; Kaelin, W.G., Jr. Regulation of mTOR function in response to hypoxia by REDD1 and the TSC1/TSC2 tumor suppressor complex. Genes Dev. 2004, 18, 2893-2904. [CrossRef]

9. Vadysirisack, D.D.; Baenke, F.; Ory, B.; Lei, K.; Ellisen, L.W. Feedback control of p53 translation by REDD1 and mTORC1 limits the p53-dependent DNA damage response. Mol. Cell. Biol. 2011, 31, 4356-4365. [CrossRef]

10. Molitoris, J.K.; McColl, K.S.; Swerdlow, S.; Matsuyama, M.; Lam, M.; Finkel, T.H.; Matsuyama, S.; Distelhorst, C.W. Glucocorticoid elevation of dexamethasone-induced gene 2 (Dig2/RTP801/REDD1) protein mediates autophagy in lymphocytes. J. Biol. Chem. 2011, 286, 30181-30189. [CrossRef]

11. Wang, H.M.; Kubica, N.; Ellisen, L.W.; Jefferson, L.S.; Kimball, S.R. Dexamethasone represses signaling through the mammalian target of rapamycin in muscle cells by enhancing expression of REDD1. J. Biol. Chem. 2006, 281, 39128-39134. [CrossRef] [PubMed]

12. Jin, H.O.; Seo, S.K.; Woo, S.H.; Kim, Y.S.; Hong, S.E.; Yi, J.Y.; Noh, W.C.; Kim, E.K.; Lee, J.K.; Hong, S.I.; et al. Redd1 inhibits the invasiveness of non-small cell lung cancer cells. Biochem. Biophys. Res. Commun. 2011, 407, 507-511. [CrossRef] [PubMed]

13. Ben Sahra, I.; Regazzetti, C.; Robert, G.; Laurent, K.; Le Marchand-Brustel, Y.; Auberger, P.; Tanti, J.F.; Giorgetti-Peraldi, S.; Bost, F. Metformin, independent of AMPK, induces mTOR inhibition and cell-cycle arrest through REDD1. Cancer Res. 2011, 71, 4366-4372. [CrossRef] [PubMed]

14. Hoeffer, C.A.; Klann, E. mTOR signaling: At the crossroads of plasticity, memory and disease. Trends Neurosci. 2010, 33, 67-75. [CrossRef] [PubMed]

15. Jaworski, J.; Sheng, M. The growing role of mTOR in neuronal development and plasticity. Mol. Neurobiol. 2006, 34, 205-219. [CrossRef]

16. Malagelada, C.; Ryu, E.J.; Biswas, S.C.; Jackson-Lewis, V.; Greene, L.A. RTP801 is elevated in Parkinson brain substantia nigral neurons and mediates death in cellular models of Parkinson's disease by a mechanism involving mammalian target of rapamycin inactivation. J. Neurosci. 2006, 26, 9996-10005. [CrossRef]

17. Malagelada, C.; Jin, Z.H.; Greene, L.A. RTP801 is induced in Parkinson's disease and mediates neuron death by inhibiting Akt phosphorylation/activation. J. Neurosci. 2008, 28, 14363-14371. [CrossRef]

18. Zhang, Z.; Chu, S.F.; Wang, S.S.; Jiang, Y.N.; Gao, Y.; Yang, P.F.; Ai, Q.D.; Chen, N.H. RTP801 is a critical factor in the neurodegeneration process of A53T alpha-synuclein in a mouse model of Parkinson's disease under chronic restraint stress. Br. J. Pharmacol. 2018, 175, 590-605. [CrossRef]

19. Kim, J.R.; Lee, S.R.; Chung, H.J.; Kim, S.; Baek, S.H.; Kim, J.H.; Kim, Y.S. Identification of amyloid beta-peptide responsive genes by cDNA microarray technology: Involvement of RTP801 in amyloid beta-peptide toxicity. Exp. Mol. Med. 2003, 35, 403-411. [CrossRef] 
20. Ota, K.T.; Liu, R.J.; Voleti, B.; Maldonado-Aviles, J.G.; Duric, V.; Iwata, M.; Dutheil, S.; Duman, C.; Boikess, S.; Lewis, D.A.; et al. REDD1 is essential for stress-induced synaptic loss and depressive behavior. Nat. Med. 2014, 20, 531-535. [CrossRef]

21. Li, C.; Gotz, J. Somatodendritic accumulation of Tau in Alzheimer's disease is promoted by Fyn-mediated local protein translation. EMBO J. 2017, 36, 3120-3138. [CrossRef] [PubMed]

22. Mata, M.A.; Satterly, N.; Versteeg, G.A.; Frantz, D.; Wei, S.G.; Williams, N.; Schmolke, M.; Pena-Llopis, S.; Brugarolas, J.; Forst, C.V.; et al. Chemical inhibition of RNA viruses reveals REDD1 as a host defense factor. Nat. Chem. Biol. 2011, 7, 712-719. [CrossRef] [PubMed]

23. Skendros, P.; Chrysanthopoulou, A.; Rousset, F.; Kambas, K.; Arampatzioglou, A.; Mitsios, A.; Bocly, V.; Konstantinidis, T.; Pellet, P.; Angelidou, I.; et al. Regulated in development and DNA damage responses 1 (REDD1) links stress with IL-1 beta-mediated familial Mediterranean fever attack through autophagy-driven neutrophil extracellular traps. J. Allergy Clin. Immunol. 2017, 140, 1378-1387. [CrossRef] [PubMed]

24. Yi, J.H.; Baek, S.J.; Heo, S.; Park, H.J.; Kwon, H.; Lee, S.; Jung, J.; Park, S.J.; Kim, B.C.; Lee, Y.C.; et al. Direct pharmacological Akt activation rescues Alzheimer's disease like memory impairments and aberrant synaptic plasticity. Neuropharmacology 2018, 128, 282-292. [CrossRef]

25. Park, J.A.; Lee, C.H. Time-Course Change of Redd1 Expressions in the Hippocampal CA1 Region Following Chronic Cerebral Hypoperfusion. Cell. Mol. Neurobiol. 2017, 37, 563-569. [CrossRef]

26. Pastor, F.; Dumas, K.; Barthelemy, M.A.; Regazzetti, C.; Druelle, N.; Peraldi, P.; Cormont, M.; Tanti, J.F.; Giorgetti-Peraldi, S. Implication of REDD1 in the activation of inflammatory pathways. Sci. Rep. 2017, 7, 7023. [CrossRef]

27. Kabir, Z.D.; Lee, A.S.; Burgdorf, C.E.; Fischer, D.K.; Rajadhyaksha, A.M.; Mok, E.; Rizzo, B.; Rice, R.C.; Singh, K.; Ota, K.T.; et al. Cacna1c in the Prefrontal Cortex Regulates Depression-Related Behaviors via REDD1. Neuropsychopharmacology 2017, 42, 2032-2042. [CrossRef]

28. Xu, D.; Dai, W.; Kutzler, L.; Lacko, H.A.; Jefferson, L.S.; Dennis, M.D.; Kimball, S.R. ATF4-Mediated Upregulation of REDD1 and Sestrin2 Suppresses mTORC1 Activity during Prolonged Leucine Deprivation. J. Nutr. 2020, 150, 1022-1030. [CrossRef]

29. Hugon, J.; Mouton-Liger, F.; Dumurgier, J.; Paquet, C. PKR involvement in Alzheimer's disease. Alzheimers Res. Ther. 2017, 9, 83. [CrossRef]

30. Paquet, C.; Mouton-Liger, F.; Meurs, E.F.; Mazot, P.; Bouras, C.; Pradier, L.; Gray, F.; Hugon, J. The PKR activator PACT is induced by Abeta: Involvement in Alzheimer's disease. Brain Pathol. 2012, 22, 219-229. [CrossRef]

31. Dennis, M.D.; Coleman, C.S.; Berg, A.; Jefferson, L.S.; Kimball, S.R. REDD1 enhances protein phosphatase 2A-mediated dephosphorylation of Akt to repress mTORC1 signaling. Sci. Signal. 2014, 7, ra68. [CrossRef] [PubMed]

32. DeYoung, M.P.; Horak, P.; Sofer, A.; Sgroi, D.; Ellisen, L.W. Hypoxia regulates TSC1/2-mTOR signaling and tumor suppression through REDD1-mediated 14-3-3 shuttling. Genes Dev. 2008, 22, 239-251. [CrossRef] [PubMed]

33. Pereyra, M.; Katche, C.; de Landeta, A.B.; Medina, J.H. mTORC1 controls long-term memory retrieval. Sci. Rep. 2018, 8, 8759. [CrossRef] [PubMed]

34. Artinian, J.; Jordan, A.; Khlaifia, A.; Honore, E.; La Fontaine, A.; Racine, A.S.; Laplante, I.; Lacaille, J.C. Regulation of Hippocampal Memory by mTORC1 in Somatostatin Interneurons. J. Neurosci. 2019, 39, 8439-8456. [CrossRef]

35. Takei, N.; Nawa, H. mTOR signaling and its roles in normal and abnormal brain development. Front. Mol. Neurosci. 2014, 7, 28. [CrossRef]

36. Koscielny, A.; Malik, A.R.; Liszewska, E.; Zmorzynska, J.; Tempes, A.; Tarkowski, B.; Jaworski, J. Adaptor Complex 2 Controls Dendrite Morphology via mTOR-Dependent Expression of GluA2. Mol. Neurobiol. 2018, 55, 1590-1606. [CrossRef]

37. Wang, Y.; Barbaro, M.F.; Baraban, S.C. A role for the mTOR pathway in surface expression of AMPA receptors. Neurosci. Lett. 2006, 401, 35-39. [CrossRef]

38. Bevilaqua, L.R.M.; Cammarota, M. PERK, mTORC1 and eEF2 interplay during long term potentiation: An Editorial for 'Genetic removal of eIF2a kinase PERK in mice enables hippocampal L-LTP independent of mTORC1 activity' on page 133. J. Neurochem. 2018, 146, 119-121. [CrossRef] 
39. An, W.L.; Cowburn, R.F.; Li, L.; Braak, H.; Alafuzoff, I.; Iqbal, K.; Iqbal, I.G.; Winblad, B.; Pei, J.J. Up-regulation of phosphorylated/activated p70 S6 kinase and its relationship to neurofibrillary pathology in Alzheimer's disease. Am. J. Pathol. 2003, 163, 591-607. [CrossRef]

40. Caccamo, A.; De Pinto, V.; Messina, A.; Branca, C.; Oddo, S. Genetic reduction of mammalian target of rapamycin ameliorates Alzheimer's disease-like cognitive and pathological deficits by restoring hippocampal gene expression signature. J. Neurosci. 2014, 34, 7988-7998. [CrossRef]

41. Caccamo, A.; Majumder, S.; Richardson, A.; Strong, R.; Oddo, S. Molecular interplay between mammalian target of rapamycin (mTOR), amyloid-beta, and Tau: Effects on cognitive impairments. J. Biol. Chem. 2010, 285, 13107-13120. [CrossRef] [PubMed]

42. Spilman, P.; Podlutskaya, N.; Hart, M.J.; Debnath, J.; Gorostiza, O.; Bredesen, D.; Richardson, A.; Strong, R.; Galvan, V. Inhibition of mTOR by rapamycin abolishes cognitive deficits and reduces amyloid-beta levels in a mouse model of Alzheimer's disease. PLoS ONE 2010, 5, e9979. [CrossRef] [PubMed]

43. Ma, T.; Hoeffer, C.A.; Capetillo-Zarate, E.; Yu, F.; Wong, H.; Lin, M.T.; Tampellini, D.; Klann, E.; Blitzer, R.D.; Gouras, G.K. Dysregulation of the mTOR pathway mediates impairment of synaptic plasticity in a mouse model of Alzheimer's disease. PLoS ONE 2010, 5, e12845. [CrossRef] [PubMed]

44. Lafay-Chebassier, C.; Paccalin, M.; Page, G.; Barc-Pain, S.; Perault-Pochat, M.C.; Gil, R.; Pradier, L.; Hugon, J. $\mathrm{mTOR} / \mathrm{p} 70 \mathrm{S6k}$ signalling alteration by Abeta exposure as well as in APP-PS1 transgenic models and in patients with Alzheimer's disease. J. Neurochem. 2005, 94, 215-225. [CrossRef] [PubMed]

45. Buffington, S.A.; Huang, W.; Costa-Mattioli, M. Translational control in synaptic plasticity and cognitive dysfunction. Annu. Rev. Neurosci. 2014, 37, 17-38. [CrossRef]

46. Hsu, Y.T.; Li, J.; Wu, D.; Sudhof, T.C.; Chen, L. Synaptic retinoic acid receptor signaling mediates mTOR-dependent metaplasticity that controls hippocampal learning. Proc. Natl. Acad. Sci. USA 2019, 116, 7113-7122. [CrossRef]

47. Gureev, A.P.; Popov, V.N.; Starkov, A.A. Crosstalk between the mTOR and Nrf2/ARE signaling pathways as a target in the improvement of long-term potentiation. Exp. Neurol. 2020, 328, 113285. [CrossRef]

48. Grier, M.D.; West, K.L.; Kelm, N.D.; Fu, C.; Does, M.D.; Parker, B.; McBrier, E.; Lagrange, A.H.; Ess, K.C.; Carson, R.P. Loss of mTORC2 signaling in oligodendrocyte precursor cells delays myelination. PLoS ONE 2017, 12, e0188417. [CrossRef]

49. McCabe, M.P.; Cullen, E.R.; Barrows, C.M.; Shore, A.N.; Tooke, K.I.; Laprade, K.A.; Stafford, J.M.; Weston, M.C. Genetic inactivation of $\mathrm{mTORC} 1$ or $\mathrm{mTORC} 2$ in neurons reveals distinct functions in glutamatergic synaptic transmission. Elife 2020, 9, e51440. [CrossRef]

50. Sarbassov, D.D.; Ali, S.M.; Sengupta, S.; Sheen, J.H.; Hsu, P.P.; Bagley, A.F.; Markhard, A.L.; Sabatini, D.M. Prolonged rapamycin treatment inhibits mTORC2 assembly and Akt/PKB. Mol. Cell 2006, 22, 159-168. [CrossRef]

51. Park, H.J.; Kwon, H.; Lee, J.H.; Cho, E.; Lee, Y.C.; Moon, M.; Jun, M.; Kim, D.H.; Jung, J.W. beta-Amyrin Ameliorates Alzheimer's Disease-Like Aberrant Synaptic Plasticity in the Mouse Hippocampus. Biomol. Ther. (Seoul) 2020, 28, 74-82. [CrossRef] [PubMed]

52. Franklin, K.; Paxinos, G. Paxinos and Franklin's the Mouse Brain in Stereotaxic Coordinates, Compact; Academic Press: Cambridge, MA, USA, 2019.

Publisher's Note: MDPI stays neutral with regard to jurisdictional claims in published maps and institutional affiliations.

(C) 2020 by the authors. Licensee MDPI, Basel, Switzerland. This article is an open access article distributed under the terms and conditions of the Creative Commons Attribution (CC BY) license (http://creativecommons.org/licenses/by/4.0/). 